\title{
CHANGES OF THE SERUM ANTIBIOTIC LEVELS DURING OPEN HEART SURGERY (ceftazidim, ciprofloxacin, clindamycin)
}

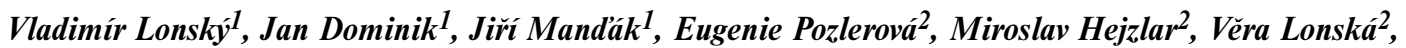 \\ Marie Maršíková ${ }^{1}$, Jaroslav Kubíček ${ }^{1}$, Marie Snítilová ${ }^{2}$
}

Charles University in Prague, Faculty of Medicine in Hradec Králové: Department of Cardiosurgery'; University Teaching Hospital in Hradec Králové: Department of Clinical Microbiology ${ }^{2}$

Summary: Background: Wound, mediastinal and intracardiac infections are still very serious complications of open-heart surgey. The incidence of it is still in the range of $0,4 \%-5 \%$. The aims of our study were to assess the adequacy of regimen using ceftazidim (CTZ), ciprofloxacin (CPF) and clindamycin (CLIN) as prophylactic antibiotics and to verify whether cardiopulmonary bypass (CPB) can modify the time of antibiotic serum concentrations. That is why the serum levels of them were measured during open heart procedures. Methods: The prospective study comprised 75 consequent coronary patients randomized in to three groups receiving $1 \mathrm{~g}$ of CTZ or $400 \mathrm{mg}$ of CPF or $900 \mathrm{mg}$ of CLIN i.v. with anesthesia induction. Routine coronary surgery with left internal mammary artery harvesting, moderate body hypothermic $\left(30{ }^{\circ} \mathrm{C}\right)$ CPB with crystaloid cardioplegia was performed. Serum antibiotic levels were determined before application, with skin incision, prior CPB induction, after cardioplegia infusion, every 20 minutes of CPB, prior end of CPB, in time of chest closure. Conventional cylinder - plate microbiological assay was used for antibiotic levelmeasurement. Results: All serum antibiotic concentrations showed a sharp decrease immediately after starting CPB and lasted until CPB ended. After initiating of CPB after cardioplegia administration serum concentrations of CTZ (105 min after initial dose) decreased by, on average $55 \%$, CPF ( $97 \mathrm{~min}$ ) by $42 \%$ and CLIN ( $116 \mathrm{~min}$ ) by $78 \%$. Conclusion: CPB can modify the time course of antibiotic serum concentrations. The serum levels of CTZ at the end of the longest procedures were found to be below the MICs for some of the suspected pathogens. We recommend to use higher antibiotic doses for prophylaxis and to administer the second dose with protamin sulphate to obtain maximum concentration in newly formed blood clots.

Key words: Cardiac surgery; Cardiopulmonary bypass; Antibiotic prophylaxis; Serum antibiotics concentrations

\section{Introduction}

Wound, mediastinal and intracardiac infections are still very serious complications of open-heart surgery. In a review article, Oakley and Wright $(1,22)$ found a reported incidence varying from 0,4 to $5 \%$. The reported prevalence rate for all nosocomial infections connected with cardiac procedures most commonly ranges from $5 \%$ to $20 \%$, but can be significantly greater among patients requiring long postoperative intensive care (13). The mortality rate of patients developing nosocomial infection ranges between $10 \%$ and $50 \%(2,4,5)$.

The antibiotic (atb) prophylaxis of bacterial infections during cardiac surgery is widely used in clinical practice since Geraci, Dale, and McGoon (8) in 1963 reported about a $10 \%$ incidence of prosthetic endocarditis with staphylococci, and the benefit of it has been confirmed in the meantime in controlled studies by several authors $(6,7,9,14,15,19,21,26$,$) .$
It is generally agreed that the success of prophylaxis is dependent on the ability to reach and maintain free antibiotic concentrations in tissues higher than the minimum inhibitory concentrations (MICs) for the most common suspected pathogens and must remain at these concentrations throughout the operation. There is also evidence that effective antimicrobial prophylaxis is mainly due to an exposure to antibiotics during the operation period, as continuation of therapy after surgery does no achieve better clinical results than single day administration (26).

Until recently Staphylococcus aureus and epidermidis are still the pathogens most frequently involved in infective complications of cardiopulmonay bypass (CPB) surgery $(10,12,17,19,23,24,25,26)$. At present we can observe the increase of Gram-negative infections too, especially caused by Pseudomonas aeruginosa, Enterobacter species, Acinetobacter species (16).

The aims of our study were to assess the adequacy of our regimen using ceftazidim (CTZ) (KEFADIM LILLY, Eli 
Lilly, Italia S.p.A.,Sesto Florentino,Italy), ciprofloxacin (CPF) (CIPRINOL ${ }^{\circledR}$ KRKA p.o., Novo Mesto, Slovenia) and clindamycin (CLIN) (DALACIN C TM UPJOHN,s.a.-PuursBelgium) as prophylactic antibiotics and to verify whether CPB can modify the time course of antibiotic serum concentrations. That is why the serum levels of them were measured during open-heart procedures. Our results were compared to standard producers data obtained after administration of $1 \mathrm{~g}$ of CTZ, $200 \mathrm{mg}$ of CPF (we were not able to find in the literature the standard curve after the dose of $400 \mathrm{mg}$ ) and $900 \mathrm{mg}$ of CLIN to healthy volunteers.

We have chosen three different types of antibiotics which represents three different groups of them (cephalosporin group, chinolone group and lincomycine group) for our study. Ceftazidim and ciprofloxacin are not routinely used for prophylaxis at our department and were used as the model ones only. Clindamycin we have routinely used for prophylaxis in former years as the antistaphylococcal agent

\section{Methods}

The prospective study comprised 75 consequent coronary patients randomized in three groups. In Group 1 - 1 $\mathrm{g}$ of CTZ i.v. (basic antibiotic dose) was given with anesthesia induction, 8 hours further dosage interval, 48 hours prophylaxis was used. In Group 2 - $400 \mathrm{mg}$ of CPF i.v. (medium antibiotic dose) was given with anesthesia induction, 12 hours further dosage interval, 48 hours prophylaxis was used. In Group 3 - 900 mg of CLIN i.v. (medium antibiotic dose) was given with anesthesia induction, 8 hours further dosage interval, 48 hours prophylaxis was used. The doses of antibiotics were chosen on the basis of producers recommendation. The dose $1 \mathrm{~g}$ for $\mathrm{CTZ}$ is recommend for treatment of noncomplicated cases, the dose $400 \mathrm{mg}$ of CPF and $900 \mathrm{mg}$ of CLIN are recommend for treatment of complicated infective cases. We wanted to follow the antibiotic levels after different doses of them.

There were no detectable differences between each group of patients with regard to demographics in our operative details (age, sex, body surface, number of grafts etc.). We have performed routine coronary surgery with LIMA harvesting. Standard cardiopulmonary bypass, SAFE II closed oxygenating system (POLYSTAN A/S, Vaerlose, Denmark), $30{ }^{\circ} \mathrm{C}$ systemic hypothermia, $4{ }^{\circ} \mathrm{C}$ St. Thomas antegrade cardioplegic arrest, two-stage venous return and ascending aortic perfusion were used. Non colloid, antibiotic free priming is routinely used at our department (Tab. 1). The hematocrit levels were maintained between $20-25 \%$.

Serum antibiotic levels were determined at the following intervals (Tab. 2). Blood samples $(5 \mathrm{ml})$ were taken via arterial catheter.

Conventional cylinder-plate microbiological assay (modif. acc. Growe-Randall: „Assay Methods of Antibiotics Laboratory Manual”, 1958) was used for antibiotic levels

Tab 1: Oxygenator prime.

Hartmanns' solution

$750-1000 \mathrm{ml}$

(acc.weight)

Rheomacrodex 3\%

$500 \mathrm{ml}$

Mannitol 10\%

$1,0 \mathrm{~g} / \mathrm{kg}$

Natrium bicarbonate $8,4 \%$

$1 \mathrm{mmol} / \mathrm{kg}$

Magnesium sulphuricum 20\%

$10 \mathrm{ml}$

$2500 \mathrm{U}$

Heparin

$5 \mathrm{mg} / \mathrm{kg}$

Metylprednisolon

$1000 \mathrm{mg}$

Ascorbic acid

Tab. 2: Sampling intervals,

1. Before atb application

2. Skin incision

3. Prior CPB institution

4. After cardioplegia administration

5. Every twenty minutes of $\mathrm{CPB}$

6. Prior end of CPB

7. Chest closure

Tab. 3: Standard concentrations of ceftazidim after administration of $1 \mathrm{~g}$ i.v.
- After 1 hour
$65 \mathrm{mg} / 1$
- After 2 hours
$28 \mathrm{mg} / 1$
- After 4 hours
$10 \mathrm{mg} / 1$
- After 8 hours
$2 \mathrm{mg} / 1$

Tab. 4: Standard concentrations of ciprofloxacin after administration of $200 \mathrm{mg}$ i.v.

- After 1 hour

- After 2 hours

- After 4 hours

- After 6 hours

- After 12 hours
$3,5 \mathrm{mg} / 1$
$2,8 \mathrm{mg} / 1$
$1,1 \mathrm{mg} / 1$
$0,8 \mathrm{mg} / 1$
$0,1 \mathrm{mg} / 1$

Tab. 5: Standard concentrations of clindamycin after administration of $900 \mathrm{mg}$ i.v.
- After 30 minutes
$10,5 \mathrm{mg} / 1$
- After 1 hour
$7,65 \mathrm{mg} / 1$
- After 2 hours
$6,9 \mathrm{mg} / 1$
- After 4 hours
$4,2 \mathrm{mg} / 1$
- After 8 hours
$2,4 \mathrm{mg} / 1$

Tab. 6: MICs of ceftazidim (Univ. Teach. Hosp. Hradec Králové).

Staphylococcus aureus

Staphylococcus epidermidis

Pseudomonas aeruginosa

$\begin{array}{rc}4-8 \mathrm{mg} / 1 \\ 16 \mathrm{mg} / 1 \\ 2 & \mathrm{mg} / 1 \\ 8-16 & \mathrm{mg} / 1\end{array}$

Acinetobacter species 
Tab. 7: MICs of ciprofloxacin (Univ. Teach. Hosp. Hradec Králové).

Staphylococcus aureus Staphylococcus epidermidis

Pseudomonas aeruginosa

Enterobacter species

Klebsiella pneumoniane

$$
\begin{array}{cc}
0,25-0,5 & \mathrm{mg} / 1 \\
0,125-0,25 & \mathrm{mg} / 1 \\
0,063-0,25 & \mathrm{mg} / 1 \\
0,063-0,32 & \mathrm{mg} / 1 \\
0,063-0,125 \mathrm{mg} / 1
\end{array}
$$

Tab. 8: MICs of clindamycin (Univ. Teach. Hosp. Hradec Králové).

Staphylococcus aureus Staphylococcus epidermidis

$$
\begin{array}{r}
0,063 \mathrm{mg} / 1 \\
0,125-1,0 \mathrm{mg} / 1
\end{array}
$$

Tab. 9: Operation and cardiopulmonary bypass times.

\begin{tabular}{|c|c|c|c|}
\hline & $\begin{array}{c}\text { CTZ } \\
(\mathbf{n = 2 5})\end{array}$ & $\begin{array}{c}\text { CPF } \\
(\mathbf{n = 2 5})\end{array}$ & $\begin{array}{c}\text { CLIN } \\
(\mathbf{n}=\mathbf{2 5})\end{array}$ \\
\hline $\begin{array}{c}\text { Operation times } \\
\text { (min) }\end{array}$ & $220 \pm 41$ & $199 \pm 40$ & $223 \pm 21$ \\
$(130-310)$ & $(145-300)$ & $(185-260)$ \\
\hline $\begin{array}{c}\text { CPB times } \\
(\mathrm{min})\end{array}$ & $78 \pm 27$ & $86 \pm 23$ & $75 \pm 16$ \\
$(40-155)$ & $(55-140)$ & $(50-155)$ \\
\hline
\end{tabular}

Tab. 10: Sampling times.

\begin{tabular}{|c|c|c|c|}
\hline $\begin{array}{c}\text { Times from atb } \\
\text { administration to... } \\
\text { (min) }\end{array}$ & $\begin{array}{c}\text { CTZ } \\
(\mathbf{n}=\mathbf{2 5})\end{array}$ & $\begin{array}{c}\text { CPF } \\
(\mathbf{n}=\mathbf{2 5})\end{array}$ & $\begin{array}{c}\text { CLIN } \\
(\mathbf{n}=\mathbf{2 5})\end{array}$ \\
\hline ...skin incision & $45 \pm 8$ & $41 \pm 12$ & $45 \pm 10$ \\
\hline ..to prebypass phase & $87 \pm 21$ & $77 \pm 18$ & $94 \pm 18$ \\
\hline ..to cardioplegia & $105 \pm 24$ & $97 \pm 20$ & $116 \pm 20$ \\
\hline $\begin{array}{c}\text {..to the end of the } \\
\text { longest procedures }\end{array}$ & $298 \pm 6$ & $266 \pm 22$ & $235 \pm 14$ \\
\hline
\end{tabular}

measurement. Morganella morganii CRM 58/87 was used as the testing agent for ceftazidime, MAU 58/87 for ciprofloxacin and STAU 4223 for clindamycin. Our results were compared to standard curves (Tab. 3-5) and to MICs of some suspected pathogens (Tab. 6-8) isolated from various types of samples of patients treated at our hospital during last two years and which were the most frequent pathogens causing infective complications at our department.

\section{Results}

The mean operation times (including anesthesia induction) and cardiopulmonary bypass times are summarised in Table 9. There were no significant differences in times between our three groups of patients.

The times from antibiotic administration to various phases of operations are shown in Table 10. Time courses of mean antibiotic serum concentrations measured during procedures are in Fig. 1-3. After the initial doses of antibiotics, their levels rapidly increased and at the time of skin
Fig. 1: The mean serum concentrations of ceftazidim during open heart surgery.

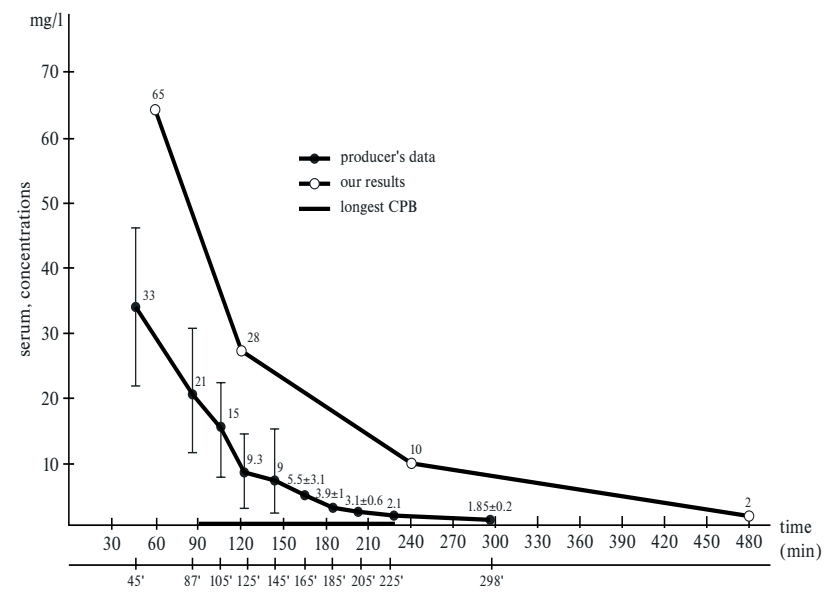

Fig. 2: The mean serum concentrations of ciprofloxacin during open heart surgery.

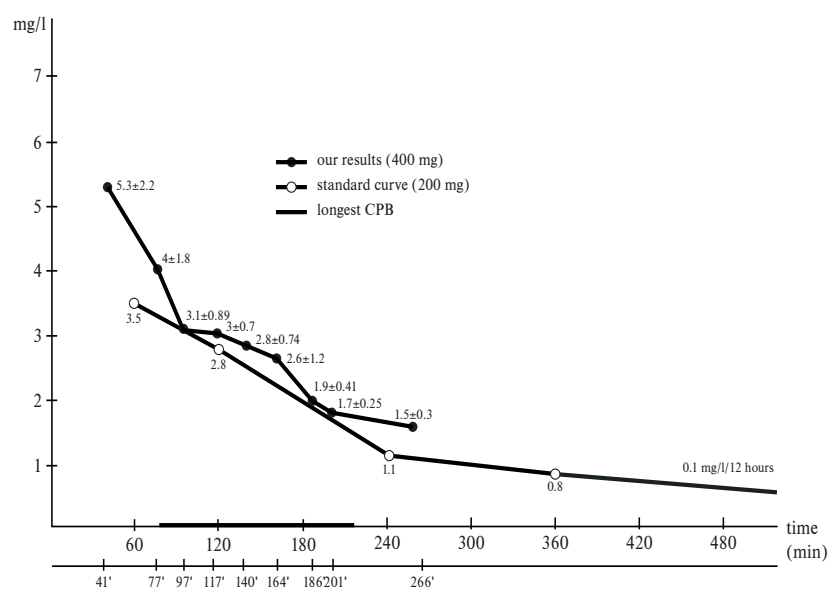

Fig. 3: The mean serum concentrations of clindamycin during open heart surgery.

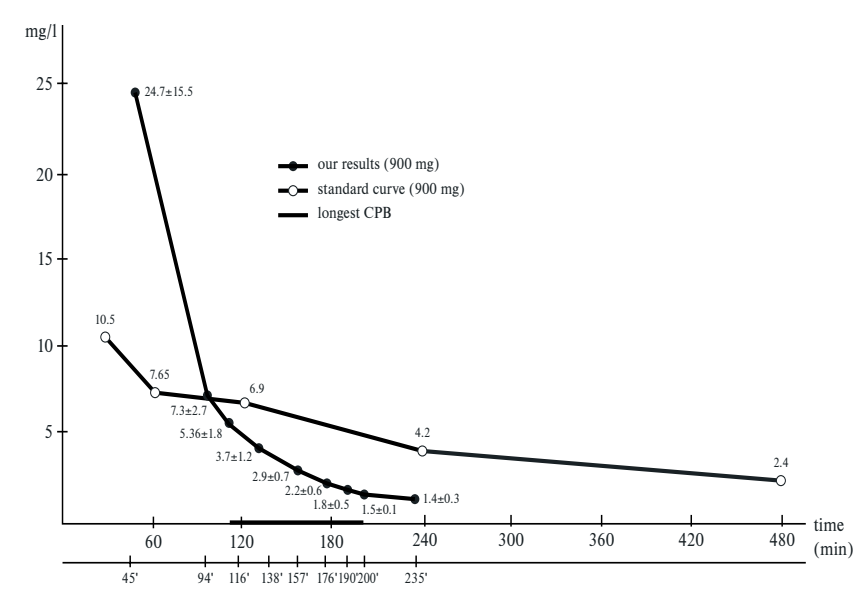


incision were in sufficient antibacterial concentrations to protect the patients against suspected infection. The antibiotic levels of CPF and CLIN (Fig. 2-3) were, even, above the concentrations in standard groups of patients. All serum concentrations show a sharp decrease immediately after starting CPB and lasted until CPB ended. The corresponding expected antibiotic serum concentrations based on producers data after the same doses are called „standard curve" (in the group of CPF are our results after the dose of $400 \mathrm{mg}$ compared to standard curve after the dose of 200 $\mathrm{mg}$, because we could not find the producers data after the dose $400 \mathrm{mg}$ ) are shown in parallels (Fig. 1-3). After initiating of CPB after cardioplegia administration serum concentration of CTZ ( 105 min after initial dose) decreased by, on average $55 \%$, serum concentrations of CPF (97 min after initial dose) decreased by, on average $42 \%$ and serum concentrations of CLIN (116 min after initial dose) decreased by, on average, $78 \%$ and the concentrations of all antibiotics remained significantly lower than the expected values throughout the operation.

Comparing the antibiotic serum levels to the MICs for some of suspected pathogens (Tab 6-8) we can see, that serum levels of CTZ at the end of the longest procedures were below the MICs for some of them. It means at the end of these procedures the prophylaxis was not adequate.

Despite of the low levels of antibiotics at the end of the longest procedures no infective complication in the group of CTZ was observed and only one wound infective complication in CLIN group of patients was found.

\section{Discussion}

The onset of cardiopulmonary bypass is associated with profound physiological changes affecting the pharmacokinetic behaviour of prophylactic antibiotics. Hypotension, hypothermia, haemodilution, lung isolation, the administration of other agents and ischaemic injury to the kidneys can alter the clearance and volume distribution (11).

As pointed out by Buylaert et al. (3) the decrease in drug serum concentrations at the onset of CPB is mainly due to an increase in volume of distribution. Many factors may underline this pharmacokinetic alteration such as an increase in blood volume, plasma protein dilution, drug binding to CPB apparatus, and drug-protein displacement by heparin-induced free fatty acid increase (19).

Our data shows that CPB can modify the time course of ceftazidim, ciprofloxacin and clindamycin serum concentrations. A sharp decrease in drug concentrations occured at the start of $\mathrm{CPB}$ and lasted until $\mathrm{CPB}$ ended. We have found the initial decrease in serum concentrations of CTZ (- 55\%), CPF (- 42\%) and CLIN (-78\%). The initial decrease in serum concentrations of teicoplanin (-35\%) and $(-40 \%)$ in connection with CPB has reported Miglioli et al. $(19,20)$ and Wilson et al. $(25,26)$.

The decrease of serum concentrations of cephazolin and oxacilin in connection with CPB is described by the author et al. (15). We have observed, that plasma levels fall below the MIC for antistaphylococcal action after $180 \mathrm{mi}-$ nutes and 150 minutes respectively. Comparing the antibiotic levels to the phase of operation, the lowest levels occured at the end of the CPB.

On the other side Heylen et al. (11) assayed serum and urinary concentrations of gentamicin during open heart surgery and in the early postoperative period. Despite the effects of $\mathrm{CPB}$, therapeutic serum gentamicin levels were maintained during surgery and reduced renal excretion in the postoperative period was associated with raised levels.

On the basis of our results and literature data we can conclude that as a result of the alteration that occur in drug distribution on cardiopulmonary bypass, standard antibiotic regimens may not be appropriate. In some situations the antibiotic prophylaxis can be inadequate. That is why some authors recommend to administer the second antibiotic dose during operation to keep the antibiotic concentrations above the MICs for suspected pathogens. Menges et al. (18) suggest to administer the second dose of $2 \mathrm{~g}$ of cefamandole after onset of CPB. Lonský et al. (15) administer the second dose of antibiotic at the same time as Protamine Suphate infusion after removing the aortic perfusion cannula to obtain maximum antibiotic concentration in newly formed blood clots.

Our dosage regimen in this study was based on producers recommendations. On the basis of our results we have changed our protocol of antibiotic prophylaxis. We have started to use the second dose of antibiotic prior to Protamin Sulphate infusion again and we use higher antibiotic doses.

The study is supported by grant No. 4103-3 of IGA of Czech Ministry of Health.

\section{References}

1. Antunes PE, Bernardo JE, Eugénio L, Ferrao de Oliveira J, Antunes MJ Mediastinitis after aorto-coronary bypass surgery. Eur J Cardio-Thorac Surg 1997;12:443-9.

2. Bellchambers J, Harris JM, Cullinan P, Gaya H, Pepper JR. A prospective study of wound infection in coronary artery surgery. Eur J Cardio-thorac Surg 1999; 15:45-50.

3. Buylaert WA, Herregods LL, Mortier EP, Bogaert MG. Cardiopulmonary bypass and the pharmacokinetics of drugs. An update. Clin Pharmacokinetics 1989;17:10-26.

4. Casha AR, Yang L, Kay PH, Saleh M, Cooper GJ. A biochemical study of median sternotomy closure techniques. Eur J Cardio-Thorac Surg 1999;15:365-9.

5. El Gamel A, Yonan NA, Hassan R et al. Treatment of Mediastinitis: Early Modified Robicsek Closure and Pectoralis Major Advancement Flaps. Ann Thorac Surg 1998;65:41-7.

6. Fekety F, Cluff L, Sabiston D, Seidl L, Smith J, Thoburn R. A study of antibiotic prophylaxis in cardiac surgery. J Thorac Cardiovasc Surg 1969;57:757-63.

7. Fong I, Baker C, McKee D. The value of prophylactic antibiotics in aorta-coronary bypass operations. J Thorac Cardiovasc Surg 1979;78:908-13.

8. Geraci JE, Dale AJ, McGoon DC. Bacterial endocarditis and endarteritis following cardiac operations. Wis Med J 1963;62:302-15.

9. Goodman J, Schaffner W, Collins H, Battersby E, Koenig M. Infection After cardiovascular surgery. N Engl J Med 1968;278:117-23.

10. Grossi EA, Culliford AT, Krieger KH et al. A survey of 77 major infections complications of median sternotomy: a review of 7949 consecutive operative procedures. Ann Thorac Surg 1985;40:214-21.

11. Heylen RM, Wilson APR, Hichens M et al. Clearance of gentamicin during cardiac surgery. J Antimicrob Chemother 1995;35:649-55. 
12. Ko W, Lazenby WD, Zelano JA, Isom WO, Krieger KH. Effects of shaving methods and intraoperative irrigation on supperative mediastinitis after bypass operations. Ann Thorac Surg 1992;53:301-5.

13. Kollef MH, Sharpless L, Vlastnik J, Pasque Ch, Murphy D, Fraser V. The Impac of Nosocomial Infections on Patient Outcome Following Cardiac Surgery. Ches 1997:112:666-75

14. Kreter B, Woods M. Antibiotic prophylaxis for cardiothoracic operations. J Thorac Cardiovasc Surg 1992;104:590-9.

15. Lonský V, Mandák J, Lonská V, Rozsíval V, Marková D, Kubiček J. Serum oxacilin and cephazolin levels during cardiopulmonary bypass. Perfusion 1992;7:115-

16. Lonský V, Dominik J, Lonská V et al. Kinetika ceftazidimu při profylaktické aplikaci u kardiopulmonálního bypassu. Acta Medica (Hradec Králové) Supp 1999;42:57-9.

17. Loop FD, Lytle BW, Cosgrove DM et al. Sternal wound complications after isolated coronary artery bypass grafting: early and late mortality, morbidity and cost of care. Ann Thorac Surg 1990;49:179-87.

18. Menges T, Sablotzki A, Welters I, Wagner RM, Zickman B, Gronau S. Concentration of cefamandole in plasma and tissues of patients undergoing cardiac surgery: the influence of different cefamandole dosage. J Cardiothorac Vasc Anesth 1997;11:565-70.

19. Miglioli PA, Merlo F, Fabbri A, Padrini R. Teicoplanin concentrations in serum, pericardium, pericardial fluid and thoracic wall fat in patients undergoing cardiopulmonary bypass surgery. J Antimicrob Chemother 1997;39:229-33.

20. Miglioli PA, Merlo F, Campanile F, Padrini R. Effects of cardiopulmonary bypas on teicoplanin serum disposition. Int J Clin Pharmacology Research 1995;15:23-

21. Niederhäuser U, Vogt M, Vogt P, Genoni M, Künzli A, Turina MI. Cardiac surgery in a high-risk group of patients: Is prolonged postoperative antibiotic prophylaxis effective? J Thorac Cardivasc Surg 1997;114:162-8.
22. Oakley RM, Wright JE. Postoperative mediastinitis: classification and management. Ann Thorac Surg 1996;61:1030-6.

23. Thompson RL, Cabezudo I, Wenzel RP. Epidemiology of nosocomial infections caused by methicillin-resistant Staphylococcus aureus. Ann Int Med 1982;97:309-

24. Wilson APR, Taylor B, Treasure T et al. Antibiotic prophalaxis in cardiac surgery: serum and tussue levels of teicoplanin, flucloxacilin and tobramycin. J Antimicrob Chemother 1988;21:201-12.

25. Wilson APR, Treasure T, Gruneberg RN, Sturridge MF, Ross DN. Antibiotic prophylaxis in cardiac surgery: a prospective comparison of two dosage regimens of teicoplanin with a combination of flucloxacilin and tobramycin. J Antimicrob Chemother 1988;21:213-23.

26. Wilson APR. Antibiotic prophylaxis in cardiac surgery. J Antimicrob Chemother $1988 ; 21: 522-4$.

Submitted November 1999.

Accepted march 2000.

MUDr. Vladimír Lonský, Ph.D.,

Charles University in Prague, Faculty of Medicine in Hradec Králové, Department of Cardiosurgery, 50005 Hradec Králové, Czech Republic. e-mail:vlonsky@usa.net 